\title{
PREFACE
}

\section{FILM AS HAGGADAH}

\author{
TOWARD A BETTER UNDERSTANDING \\ OF AMERICA'S JEWS
}

There is growing recognition that feature films can be considered an important primary source for the study of twentieth-century life and our time. Since the birth of cinema, filmmakers have been providing us with films that reflect the world in which they live, and their work often affords great insights into the prevailing attitudes of that universe. Like the Haggadah, the traditional "telling" of the story of the Israelites' exodus from Egypt that is read at the Passover seder, cinema offers a valuable text from which to gain an understanding of the social, political, and cultural realities of the era. Movies provide a powerful lens, a window on the past, an opportunity for historical examination.

Narrative feature films, despite almost always being fictitious, have the capability of reflecting on historical reality. Historian and sometime film critic Arthur M. Schlesinger Jr. asserted, "The fact that film has been the most potent vehicle of the American imagination suggests all the more strongly that movies have something to tell us not just about the surfaces but about the mysteries of American life." "His observation is assuredly true for an understanding of American Jewish life. This study uses the medium of cinema to provide an understanding of the changing situation of the American Jew over the last century.

Movies convey a great deal of information, not just through story but via images and backstory - the background history of why these movies were made, who produced them, and who went to see them. The inclusion of various oral histories and interviews with principals involved in production aug- 
ments our comprehension of the films studied. Consideration of conditions surrounding film production is a key element in properly studying films. John O'Connor argued that "the cultural analysis of film demands that attention be given to the ways in which the artifact was understood by historical spectators at the time of its production and release." ${ }^{2}$ Why was this film produced? Who made it? Under what circumstances? Was the film widely distributed? Over the last half-century, historians have advanced a methodology for mining feature films for evidence of this history by contextual analysis: a close reading of the film, the circumstances of production, and the way the movie was understood by spectators at the time of its release.

Any work of this kind requires that the films themselves be carefully scrutinized and studied. Analysis of the motion picture is an essential part of this book, and that examination often focuses on specific sequences from a film, going beyond dialogue to study the visual symbols that are present in the motion picture and that bring about a reaction from the spectator. These sensory symbols, as K. R. M. Short observed, "are extremely important in creating the appropriate emotional response or climate among the audience" and often "are so deeply part of a particular social or historical context that the 'foreign observer' may be unaware of their emotive value." ${ }^{3}$ They may trigger an emotional response with one audience and go unnoticed by another. When Jakie Rabinowitz holds up a prayer shawl, a tallit, in The Jaz Singer, as he is being forced to make a choice between career and religion, this triggers a particular emotional response. Whether consciously or unconsciously, the reaction from the Jewish viewer may be very different from that of the "foreign observer." In Avalon, the image of a train pulling into a station as relatives who survived the war arrive in Baltimore conjures up a very different reaction for those used to watching Holocaust films about mass forced deportations by train in Europe than it does for the uninitiated. Shot-by-shot analysis of the film provides a remarkable text for our understanding of the world that surrounds it and with which it communicates, but reactions may vary by audience.

French historian Marc Ferro noted that cinema should be seen as both a "source" of history and as an "agent" that helps shape history. ${ }^{4}$ In an examination of the 1947 feature films that openly broached anti-Semitism as a subject (chapter 3), we see that the films not only shed light on our understanding of the period, but as "agent" actually combated anti-Semitism and effected change. Robert Sklar noted about movies that "the nature of their content and control helps to shape the character and direction of American 
culture as a whole." ${ }^{5}$ The very nature of feature-film narrative draws one in and encourages the spectator to share in the experience. That experience and its entertainment function, as historian Michael Paris observes, generally reflect the "dominant ideas, attitudes and values of the culture in which the film is made." The filmgoing event also makes movies "a powerful means of mass persuasion, as it both reflects and reinforces popular ideas and preoccupations and inculcates views and attitudes deemed desirable by the filmmaker and wider society." "As film historian John Belton put forward, these fictional works have a "use-value." "They can be analyzed - even psychoanalyzed - to reveal something about the cultural conditions that produced them and attracted audiences to them." 7 The thrust of this study rests on the assumption that feature film can effectively be used as text for the study of the American Jewish experience, Jewish identity, and Jewish culture.

In the first half of the twentieth century, Hollywood's movie moguls, most of whom were Jewish, shied away from asserting a Jewish image on the screen for fear that they might be too closely identified with that representation. As Sklar pointed out, "The movies were the first medium of entertainment and cultural information to be controlled by men who did not share the ethnic and religious backgrounds of the traditional cultural elites." ${ }^{8}$ Over the next two decades, Jewish moviemakers became more comfortable with the concept of a Jewish hero and with an overpowered, yet heroic, Israel. Then, as there was greater comfort broaching the topic of the Holocaust, it assumed center stage as the single greatest event impacting Jewish identity in America. Over the last two decades, American Jewish screenwriters, directors, and producers have become increasingly comfortable with their heritage. As a result, we are seeing an unprecedented number of movies that spotlight Jewish protagonists, experiences, and challenges. Just what are these critical Jewish visuals that have dominated the screen, and what is the inherent coding within these images?

Jews have been involved in the production of motion pictures since the beginning of filmmaking in America and have also been the subject of many of those films. In an industry strongly influenced by Jewish moviemakers who made and continue to make the decisions as to which films are produced, the complex and changing nature of the American Jewish condition has had considerable impact on American cinema and, in particular, on how Jews are reflected on the screen. If we study the American Jewish experience over time through the cinematic lens, we are able to see an evolving portrait of the American Jew over the last century: where Jews have been and pos- 
sibly where they are going. A corpus of movies has recorded the evolution of Jews within America over the last century, and the cinema provides a meaningful and real accounting - a way of telling the story, a Haggadah of what has transpired for Jews in America and what continues to take place. Through movies, we can better understand America's Jews and the changes in America that had an impact on United States Jewry. Film historian Peter Rollins wrote that "films can serve the student of American culture in a far more interesting way than simply as a record of visual reality, for films register the feelings and attitudes of the periods in which they are made." 9 A close study of the film text, the visual images, and the coding within the film offers a great deal of information. This book is an effort to explore the American Jewish story of the last century through a review and study of some of the outstanding examples of this film genre.

The book approaches the American Jewish experience by analyzing select mainstream films from the beginning of the sound era to today. Though many motion pictures lend themselves to study and interpretation, and the omission of some was often difficult, I have chosen select films that I consider representative of specific historical periods. By studying these Jewish subject films and their production history, we gain entrée into the changing and evolving sensibilities of the American Jew.

Woven through the study are insights from some of the creative participants in the making of these films, many of whom were interviewed by the author. Each chapter takes the critical memories and seminal events and looks at how these artists interpreted their subjects to provide an understanding of their time. With the evolution of independent cinema, the growth of film festivals, and changes in technology, cinema should, more than ever before, become an important text for better understanding the journey of Jews in America.

The idea for this book grew out of a number of experiences. While still a graduate student in cinema studies at New York University, I was introduced to Oscar Cohen, who was National Program Director at the AntiDefamation League of B'nai B'rith. Cohen asked for my help in doing some research for a project, a possible book, that he was undertaking on "Jews and Movies." It was my first introduction to the subject of how Jews were involved in the American film industry, and I found it unquestionably eyeopening. That was over thirty-five years ago, and the question of how Jews are reflected in film has since been ably documented in several fine works by 
authors like Patricia Erens, Lester Friedman, and Neal Gabler. I know that Oscar would be pleased.

In I988, while curating a film series of American Jewish-subject films at the 92nd Street $\mathrm{Y}$ in New York, a few acquaintances got together and talked about how best to use such films in an educational setting in order to stimulate a discussion about the American Jewish experience. The most enthusiastic of the group was Paul Cowan, who had recently authored An Orphan in History. I remember having several conversations with Paul about how film should be used as "text" for understanding the American Jewish experience. In fact, it was Paul's strong commitment to this idea that led this same group to create a video mini-course, The Golden Land on the Silver Screen, using cinema to explore American Jewish life, which is referenced in the filmography. We came up with the idea to film six short introductions and postscreening wrap-ups on American films that we considered important. Paula Hyman, Egon Mayer, Deborah Dash Moore, and Mordecai Newman joined Paul and me in tackling one film each. Michael Strassfeld supervised the effort. The segments were meant to precede and follow the screening of each particular film. It was a unique approach to using the then-new technology of video for education, and the experience left me wanting to do more.

As a cinema studies student in the late I970s at New York University, I was deeply affected by the new approaches to cinema history brought to bear by some of my teachers. The influence of Jay Leyda, who revolutionized film history by focusing on production history and how various production events impact cinema, was incredibly strong. He encouraged me to take production histories from such filmmakers as Dore Schary and Elia Kazan (which are incorporated into this book), even though their personal politics and experience within the film industry were so totally opposite Jay's. He taught me how to "read" film text and what is required of a good film historian. Robert Sklar came to NYU just as I was completing my studies, but our paths crossed long enough for me to appreciate and adopt his approach in using Hollywood film as a lens for analyzing American society. Other teachers like William Everson, William Rothman, William Simon, and Donald Staples also influenced how I began to use cinema as a text that required deciphering. I am so deeply grateful for that incredible learning experience.

In order to study the changing situation of Jews in American society, one requires a thorough understanding and appreciation of American Jewish history. As a camper, counselor, and unit head at Camp Tel Yehudah, 
I became intoxicated with Mel Reisfield's love for Jewish history, and this enthusiasm remains with me to this day. Bernard Reisman at Brandeis University helped clarify and define American Jewish life and the structure of the Jewish community in a manner that gives clarity to much of what I do. Others with whom I studied at Brandeis were Marshall Sklare, the penultimate American Jewish sociologist; Ben Halpern, an outstanding historian; Leon Jick, a remarkable teacher whose enthusiasm for American Jewish history was contagious; and Leonard Fein, who appreciated the power of cinema and who encouraged me to delve even deeper. My time spent studying with each provided me with a wonderful grounding in American Jewish history and culture.

The true pursuit of this book began when I was accepted as a fellow at the Center for Advanced Judaic Studies at the University of Pennsylvania just over ten years ago. It was there that I was able to turn my attention to the research that was required. With the assistance of an unbelievably supportive library staff, I finally was able to dedicate extended periods of time to working on this book. I also turned to other fellows in the program for feedback and insights, which was most helpful. Center head and historian David Ruderman was always there to encourage me, and I thank him for providing this period of incubation.

Over these last ten years, I have screened and rescreened films on video and DVD, a luxury that was not possible only a short while ago. Just a few years earlier, we would mount $\mathrm{I} 6 \mathrm{~mm}$ films on a flatbed editing table or screen works in special screening facilities, even on occasion setting out for the Museum of Modern Art to study a rare film. Today, with DVD, one can more easily and clearly see the genius of the filmmaker at work and try to better understand why a film is constructed the way it is. I am thankful to my students at Queens College of the City University of New York, Stern College for Women at Yeshiva University, and The Jewish Theological Seminary for insights that they offered in the course of together studying films that deal with Jewish life in America. Any teacher who does not learn from his or her students is not worthy of being called an educator.

There have been many people, foundations, and organizations who were most helpful and whom I wish to thank. Daniel Huberman was my first research assistant; he spent hours poring over the files of local research libraries. Benny Kraut invited me to teach at Queens College and joined me in planning and implementing a 2004 national symposium on "The American Jewish Experience as Reflected in Film.” Always ready to assist were 
the librarians at New York Public Library for the Performing Arts at Lincoln Center, the Dorot Jewish Division of the New York Public Library, Yeshiva University Library, and the library of The Jewish Theological Seminary. The archive and library of the American Jewish Historical Society and Yivo Institute for Jewish Research at the Center for Jewish History in New York was also an invaluable resource. Special thanks to the archivists at American Jewish Committee and Anti-Defamation League of B'nai B'rith for allowing me access to their collections, some of which is now housed at the Center for Jewish History. The Dore Schary collection at the Wisconsin Historical Society in Madison is a treasure trove of information, and the staff was not only courteous, but also extremely helpful. Lester Friedman graciously allowed me access to his interview with Edward Dmytryk, and Nancy Kaufmann at George Eastman House in Rochester, New York, made it happen. I am thankful to the film artists who agreed to share their valuable time and respond to a variety of questions, either in person, over the phone, or by e-mail; their insights were so important to this work. Photographs included in the book are from Photofest New York, the New York Public Library, Ergo Media, the Philippe Halsman Archive, and the American Jewish Committee.

Aron Hirt-Manheimer came to me in 1975, having learned of my interest in the postwar films about anti-Semitism, and asked me to write what would be my first journal article for a special issue of Davka Magazine. Steven Bayme at the American Jewish Committee provided an early platform for my work by publishing my monograph on the subject, with Roselyn Bell making excellent editorial recommendations. Eli Faber encouraged me and edited an early article on Barry Levinson and Avalon and Liberty Heights that appeared some years ago in American Jewish History; the idea was suggested by Edna Nahshon. Richard Koffler provided support, challenged me, and meticulously reviewed my manuscript. My editors at the University of Texas Press, Lynne Chapman and Mary LaMotte Silverstein, were most constructive, a joy to work with, and incredibly helpful. My deepest gratitude to all. I am also indebted to Michael Neiditch, who first approached me to submit my manuscript to UT Press, and to Jim Burr, who shepherded the project from beginning to end. A special note of appreciation goes to the Kronhill Pletka Foundation, the Lucius N. Littauer Foundation, and the Memorial Foundation for Jewish Culture for their generous support.

Finishing this book was in part accomplished by having gone away on writing retreats. On more than one occasion, I sought solitude in the Mon- 
treal apartment of my mother-in-law, Florence Garmaise, where I was well fed and provided with quiet and total privacy. Affording oneself time to write is often harder than it might seem, but my daughters Reisha, Arielle, and Dori and son-in-law Michael were always respectful and understanding, encouraging me to complete this work. Some vacations with my wife Susan became writing weeks, where I would write in the morning and vacation in the afternoon, and I am most appreciative of her love, encouragement, and understanding. I dedicate this work to her. 
THE AMERICAN JEWISH STORY THROUGH CINEMA 
THIS PAGE INTENTIONALLY LEFT BLANK 